\title{
Introduction
}

Knowledge or science in all fields is developing so extraordinary. The development is taking place so fast according to time progress. Both natural sciences and social sciences spur themselves continually for challenges that related to human needs. For example, social sciences, including humanity, are also developing to respond social challenges that are arisen by natural sciences development, particularly biology, chemistry and physics. All three fields, which are stated, last, are fields that support life on earth. Not only will these fields be able to provide items for human life, but they will also be able to provide lethal weapons. For these reasons, social sciences are really needed their influences to respond the developments in biology, chemistry, or physics.

Biology, which one of the fields developing so fast, has already provided techniques in order to improve health and agricultural needs. Genetics, cell biology, microbiology, molecular biology, or even biochemistry, is a branch of biology that can be stated parallel with physics. These fields (e.g., genetics and biochemistry) could be stated as one field only. For example, doctoral program requirements in genetics program for core courses could consist of genetics, biochemistry, research methods in biology and rotations. Elective courses, depend on student needs, could consist of physics, etc. According to this, all techniques, which are used in molecular biology, including from physics, are also used in genetics. Genetics has primary role to improve health and agricultural needs.

Genetics is a branch of biology concerning hereditary. The man, who is responsible in modern genetics finding, is Johan Gregor Mendel. Mendel was a monk, a substitute teacher, and an amateur scientist. He could be stated as an unsuccessful teacher. He tried to take a qualification examination for a teacher, but failed. He served as a substitute teacher only. A 
remarkable history regarding Mendel's career as a teacher and his scholarly work could be read in many biology or genetics books as written by, Gerking ${ }^{1}$, Nelwan $^{3,4}$, Gardner $^{5}$, Silverstein $^{6}$, and Suryo ${ }^{7}$. There is a field called Mendelian Genetics in order to honor Gregor Mendel, too.

Since Watson and Crick introduced their DNA model, there are many researchers conducting researches that related to DNA, genes so far. Gene is a unit of DNA in chromosome. This unit consists of traits from our ancestor inherited from one generation to next generations ${ }^{3,4}$. Traits could be short and tall in human or even traits for murder and rape. In addition, techniques in computational biology and systems biology could be used in order to provide evidences for inheritance in human traits, including aggression behavior. Other techniques in biology among other things include cloning and longevity.

This paper attempted to address the following questions:

What are creation steps in Genesis 1 in the Bible reasonable based on the field of biology? Is it possible that there is life out there based on the Bible, Old Testament and New Testament? Are there evidences in behavior genetics supporting inheritance of sin as indicated in gospel? What are needed to learn biology both online and offline for Christianity and other fields need?

\section{Biology and the Bible}

The Bible does not inhibit science developments. In the Bible, there are no words for biology, chemistry, mathematics and statistics, and physics. However, words such as water, astronomy experts, and toss exist in the Bible. These words could be related to the fields of biology (water), chemistry (water), mathematics and statistics (toss; probability), and physics (astronomy). There are no notes in gospel that inhibit knowledge development related to science. For the Lord giveth wisdom: out of his mouth cometh knowledge and understanding (Prov. 2 : 6). 
In the past, some groups rejected the Bible explanations in Genesis 1 regarding the sun and life on earth. The Bible indicates that grass, herb yielding seed and the tree yielding fruit are real before creation of the sun. Opponents stated that it was impossible that plants could be life without energy from the sun. Life needed sun. However, according to time progress, it has been known that life is real without energy from the sun. After creating plants, God created animals and man. These steps of creation are not the same as the evolution theory. The evolution theory indicates that plants and animals rose on the earth at the same era hundreds of million years ago. It seems that cloning concept could answer this issue. Were plants and animals cloned? Were plants cloned before animals? It is possible based on the cloning concept.

Gene cloning is a biological technique that uses restriction enzymes, vectors and bacterial cells in order to produce manipulated genes according to aim of a research. Restriction enzymes are introduced into a main DNA to produce certain fragments. These fragments are inserted to a vector in which this vector replicated in a host cell. DNA vector and inserted foreign DNA are introduced to bacterial cells in which it multiplies. This technique use was described by Grierson and Covey using Bam H1 or Sal 1 restriction enzyme and plasmid pBR322 as a vector ${ }^{1}$. Briefly, this technique could result recombinant pBR322 plasmids that resistance or sensitive to antibiotics ${ }^{1,2}$. It could be stated that if these plasmids are introduced to organisms such as human, s/he could be resistance towards certain antibiotics as ampicillin or tetracycline. Fortunately, current antibiotics could be used to fight this kind of resistance.

Reproductive cloning is a cloning technique in order to produce differently generations with natural generations of organisms such as man, cattle, sheep, and mice. This technique is called somatic cell nuclear transfer (SCNT) and altered nuclear transfer $(A N T)^{8}$. In $\mathrm{SCNT}^{9}$, somatic cell from an adult donor (cattle or sheep) is grown in a culture dish contained nutrients. 
After growing, nutrients are removed from the culture so that cells growth stopped. One of these cells is fused with another oocyte in which the nuclear had previously been removed. The cell is fused by a simple direct electrical pulse. Within approximately a day the fused cells will begin to divide in the culture dish. After several divisions of cells up to 100 cells, the early embryo is transferred to mother's uterus using embryo transfer technique. To transfer to more than one mother, it needs estrous synchronization technique. Embryo is allowed to develop within the mother's uterus. It may be born as a normal birth.

Scientists at MIT and the Whitehead Institute for Biomedical Research, Jaenisch and Meissner, have successfully demonstrated that a theoretically technique for generating embryonic stem cells is possible. The theory is called ANT. The procedure is almost similar to SCNT. First proposed by Hurlbut, a Stanford University professor and member of the President's Council on Bioethics, ANT has been described as an ethical alternative to SCNT. In this procedure, before the donor nucleus is transferred into the egg cell, its DNA is altered so that the resulting blastocyst has no chance of ever becoming a viable embryo. It is not destroyed once stem cells have been extract ${ }^{8}$.

To do the ANT procedure, Jaenisch and Meissner focused on a gene called Cdx2, which enables an embryo to grow a placenta in order to create balastocyst. They disabled $\mathrm{Cdx} 2$ in mouse cells so that the blastocyst cannot implant in uterus. They accomplished this with a technique called RNA interference, or RNAi. Short interfering RNA (siRNA) molecules are designed to target gene and disrupt its ability to produce protein. In effect, the gene is shut off. Jaenisch and Meissner design a particular form of siRNA that shut off $\mathrm{Cdx} 2$ in the donor nucleus and then incorporated itself into all the cells comprising the blastocyst. All the resulting mouse blastocysts were incapable of implantation. After this procedure, to make $\mathrm{Cdx} 2$ available, 
Jaenisch and Meissner deleted the siRNA molecule by transferring a plasmid into each cell so that the blastocyst can implant in uterus.

\section{Life on Other Worlds?}

Scientists have invented technical methods in order to do researches on genetics manipulation for our needs. These techniques could be used to support our life on this earth. They could even be used in order to anticipate for life out there that suitable for our environment, if there is another life there. According to the Bible, it is possible to state that there is life out there. Christ is everywhere. He could already go to other places there before coming to earth around two thousand years ago. Probably we do not alone and perhaps there is life out there.

The Bible indicates that there is another creature beside us. They are not stated as foul spirits, satyr, or devil only (Mark $6: 49$, Isa. $34: 14$, Rev. $18: 2$ ). They are stated as creature (Rom. $8: 19-22$ and 39). And he said unto them, Go ye into all the world, preach the gospel to every creature (Mark $16: 15$ ). It is possible that they are as us.

Rom. $8: 19-22$

19 For the earnest expectation of the creature waitheth for the manifestation of the son of God. 20 For the creature was made subject to vanity, not willingly, but by reason of him who hath who hath subjected the same in hope.

21 Because the creature itself also shall be delivered from the bondage of corruption into the glorious liberty of the children of God.

22 For we know that the whole creation groameth and travaileth in pain together until now.

39 Nor height, nor depth, no any other creature, shall be able to separate us from love of God, which is in Christ Jesus our Lord. 
The Lord giveth knowledge and understanding to us. There is no reason to reject this opportunity. It is reasonable to think that God created places elsewhere for life before giving us this world and is creating another one, too. After the creation in Genesis 1 of the Bible man, animals and plants have reproduced generation after generation. It is reasonable to think that the universe (sun and its planets, for example) is growing from one generation to the next generation, too. There is Christ in the universe, or other places. He could come to this world and elsewhere in the universe. As his followers, it is possible for us to go there to introduce Christ; even man could be life there if something happen upon this world.

Ezek. 1 : 4 And I looked, and, behold, a whirlwind came out of the north, a great cloud, and a fire unfolding itself, and brightness was about it, and out of the midst thereof of the color of amber, out of the midst of the fire.

Ezek. $3: 12-13$ Then the spirit took me up, and I heard behind me a voice of a great rushing, saying, Blessed be the glory of the Lord from his place.

13 I heard also the noise of the wings of the living creatures that touched one another, and the noise of the wheels over against them, and a noise of a great rushing.

It has not yet been known exactly whether or not Ezekiel has met with creature from another world in which Christ had come before coming to the earth around two thousand years ago. The Bible indicates that Now it came to pass in the thirtieth year, in the fourth month, as I was among the captives by the river of Chebar, that the heavens were opened and I saw vision of God (Ezek. $1: 1)$. He did not see God but vision of God. It could be stated that he saw "God" and creatures along with him. He stated that he heard a great rushing and noise of the living creatures. It seems as creatures from other places out there came to Ezekiel and they used a 
"plane." It is possible that these creatures knew about Christ very well. If so, it seems that we do not alone and our technology is not the best in the universe.

If there is life out there, and we could go there, we could introduce our technology there, if technology there not better than us. Then cloning to plant, animal, even man could be conducted according to steps described in Genesis 1. It could be conducted as evolution theory, too.

\section{Aggression on Christianity}

Aggression is fighting for something happened among organisms such as humans, dogs and chickens. If indigenous dogs or chickens are paired with others of their kinds, fighting ensues and ones become dominant and the other subordinate. If these encounters are arranged so that a particular animal always wins, that animal becomes more and more dominant over his fellows ${ }^{3,4}$. It is fill in Gardner' $s^{5}$ explanation regarding aggression in dogs and chickens. Aggression behavior in chicken was introduced for the first time by the Norwegian scientist Schjelderup-Ebbe ${ }^{6}$. Aggression traits such as murder and rape are related to bad traits in human and are genetically inherited from our ancestors.

In Christian religion, murder and rape are bad traits called sin. These traits, according to the gospel, are inherited by Adam and Eve, the first family on the globe. Paul introduced inheritance of sin around two thousand years ago. In my opinion, science and religion must be separated. However, science could be used to show the truth items spoken in religion, particularly Christian religion. In this case, it seems that Paul is correct. Biology, in particular behavior genetics, has given opportunity to solve item for sin inheritance described in gospel.

Rom. 3 : 23-24

23 For all have sinned, and come short of the glory God; 
24 Being justified freely by his grace through the redemption that is in Christ Jesus:

Rom. 15 : 17

For by one man's offence death reigned by one; much more they which receive abundance of grace and of the gift of righteousness shall reign in life by one, Jesus Christ.

Computational biology and systems biology can explain behavior genetics patterns such as aggression or depression. These both fields assist to analyze behavior among organisms, particularly human being. Computational biology and systems biology are important fields in the modern era. It may explain traits that have been secret for a long time. For example, it has been known that aggression trait is inherited from our ancestors. Gene and its structure have been known as well. Gene, which is related to aggression, is MAOA and $\mathrm{COMT}^{10}$. Aggression trait exists in Brunner Syndrome $(\mathrm{BS})^{11}$ and Schizophrenia Syndrome $(\mathrm{SS})^{12}$, for example. Even McDermot et $\mathrm{al}^{13}$ explains more information regarding aggression.

Computational biology and systems biology are fields that include fields of science, technology, engineering, and computer science. These fields speak about analyzing and modeling. Biology, chemistry, physics, and mathematics and statistics are related to computational biology and systems biology. Science, technology, engineering, and computer science are used in order to build a multiple-disciplinary approach to the scientific analysis of complex biological phenomena. Computational biology concentrates upon using tools such as BLAST and Phylogenetic. It uses schemes, images, and models to explain the analysis. Systems biology concentrates upon mathematical modeling, images and schemes, too. Both fields are used to analyze the similarities of proteins, structures of proteins, structure of genes, etc. DNA and RNA are studied in biology and chemistry. Physics is used to analyze them both as well, for 
example. The knowledge in information technology and programming in computer science are involved in both computational biology and systems biology. Statistics is needed, too.

Tools such as ProDam database, SWISS-PROT database, and Phylogenetics, are used in computational biology to analyze and compute to have answers for hypothesis. From National Center for Biotechnology Information, it may be used BLAST. For example, BLAST is used to understand similarities of proteins or nucleotides among organisms. To explain the analysis and computation, it is used schemes, images and models. Schemes, images, and models are provided by researchers. Tools, such as ProDam database, SWISS-PROT database, and Phylogenetics, had been used to predict protein functions and protein-protein interactions. Phylogenetic had ben used to analyze protein functions.

A researcher may use tools for computational biology to introduce a method. For example, the domain fusion analysis was introduced by Marcotte et $\mathrm{al}^{14}$ in order to analyze their research. The domain fusion analysis included ProDam database, SWISS-PROT database, and Phylogenetic profiles. Also, they introduced a model and image called Rosetta stone sequences. The model and figure were for detecting evolution of proteins. Pellegrini et $\mathrm{al}^{15}$ used the Phylogenetic profiles to predict functional proteins.

With computational biology and systems biology, it is possible to know interacting proteins and protein functions among organisms such as human, mouse, and drosophila. It is possible to know the relationship of gene between Drosophila melanogaster and Homo sapiens for aggression behavior. Similarities of proteins and its functions and interactions may be predicted using techniques in computational biology and systems biology. There are many tools that can be studied for this. One of them is provided by Massachusetts Institute of Technology. 
For more information, visit web.mit.edu/7.02/resources/tutorial.shtml. Information regarding a simple method in learning BLAST, visit www.digitalworld.com/BLAST/index.html.

At the present time, it is possible to learn biology both online and offline. There are many prominent higher education institutions that provide online courses for free. Those courses could be learned offline, too. One of the higher education institutions, which provide good online courses, is Massachusetts Institute of Technology called MIT OCW. In addition, it is also possible to pursue a higher education programs based on online or offline education system as introduced by the Nelwan's Approach ${ }^{16}$.

To learn more regarding Cognitive and Behavior Genetics, Foundations of Computational and Systems Biology, or Topics in Computational and Systems Biology, it can be downloaded from MIT OCW. For example, to download Cognitive and Behavior Genetics course materials, it could be conducted using Internet Explorer and Mozilla Firefox. In this case, it will be used Mozilla Firefox. To do this, visit ocw.mit.edu and then do the following steps:

Under Find courses, click science.

Click biology.

Under courses for graduate, click Cognitive and Behavioral Genetics.

Click downloads course materials.

Click START DOWNLOAD.

Click OK.

Click 2x the downloaded materials.

Under Name, click 9-19j-spring-2001 2x.

Under Name, click START.htm 2x. 
These course materials can be sent to flash disk, too. To do this, right click downloaded course materials and then send to flash disk [usually written as KINGSTON (E:)]. By using a desktop or laptop, course materials can be learned at a hotel, home in either urban or rural area, including isolated area. Even they can be learned in the jungle.

MIT OCW and the Nelwan's Approach are useful to develop education activities in either urban or rural area, or even the jungle. People who use the Nelwan's Approach could hold academic degrees in many areas of field's such as biology, economics, and health. To pursue other degrees such as Christian religion, people could download course materials from other sources as provided by Yale University.

\section{Conclusion}

Biology is developing so fast and is giving its influence in life on earth. It seems that it gives opportunity to analyze life aspects in the fields of social sciences, humanity as religion in particular Christian religion, and education. Evidences, which are based on biology, show that it could be stated that there is no problem with creation steps in Genesis 1 of the Bible. Biology techniques could be used on other worlds out there, if there is life there. It supports $\sin$ inheritance as indicated in gospel. Biology is needed in order to open all questions related to the Bible, both Old Testament and New Testament. According to this, educational biology must be developed among individuals in Christian communities. Individual can do this by learning biology courses and other fields related to biology both online and offline. It can be learned other than biology such as health and law, too. The Nelwan's Approach may help to do that, particularly for academic degrees and professor position. The Approach can be used by everyone who would like to pursue a higher education program.

\section{References}


1. Grierson, D. and S. Covey. 1984. Plant Molecular Biology. New York: Chapman \& Hall.

2. Nelwan, M. L. 2010. An Introduction to Gene Cloning: Cloning in Plasmid pBR322 using Bam H1 Restriction Enzyme. Unpublished.

3. Nelwan, M. L. 1990. General Genetics. Unpublished.

4. Nelwan, M. L. 1991. Chicken Genetics. Unpublished.

5. Gardner, E. J. 1972. Principles of Genetics. Fourth Ed. New York: Wiley \& Sons, Inc.

6. Silverstein, A. 1974. The Biological Sciences. San Francisco: Rinehart Press.

7. Suryo. 1986. Genetika Manusia. Yogyakarta: Gadjah Mada University Press.

8. Cameron, C. 2005. Whitehead Research open door to new stem cell work. web.mit.edu/newsoffice/2005/techtalk50-6.pdf.

9. Nelwan, M. L. 2012. A Theoretical Approach: Clone in Indigenous Sheep with Somatic Cell Nuclear Transfer. Unpublished.

10. Ferguson, C. J. 2010. Genetic Contributions to Antisocial Personality and Behavior: A MetaAnalytic Review From An Evolution Perspective. The Journal of Social Psychology. 150(2): 160-180. www.tamiu.edu/ cferguson/evmeta.pdf.

11. Brunner, H. G., et al. 1993. X-Linked Borderline Mental Retardation with Prominent Behavioral Disturbance: Phenotype, Genetic Location, and Evidence for Disturbed Monoamine Metabolism. Am. J. Hum. Genet. 52: 1032-1039. www.ncbi.nlm.nih.gov/pmc/articles/PMC1682278/pdf/ajhg00064-0013.pdf.

12. Godfrey, D. P. and B. S. Foley. 2008. Schizophrenia, Psychiatric Genetics, and Darwinian Psychiatry: An Evolution Framework. Schizophrenia Bulletin. 34: 722-733. www.ncbi.nlm.nih.gov/pmc/articles/PMC2632450.

13. McDermot R. et al. 2009. Monoamine Oxidase A Gene (MAOA) Predicts Behavioral Aggression Following Provocation. ProcNatl. Acad. Sci. USA. 106: 2118-2123. www.pnas.org/content/106/7/2118.full.pdf?with-ds=yes.

14. Marcotte, E. M. et al. 1999. Detecting Protein Function and Protein-protein Interaction from Genome Sequences. Science. 285: 751-753. www.scienmag.org/content/285/5428/75.full.pdf.

15. Pellegrini, M. et al. 1999. Assigning Protein Functions by Comparative Genome Analysis: Protein Philogenetic Profiles. ProcNatl. Acad. Sci. USA. 96: 4285-4288. www.ncbi.nlm.nih.gov/pmc/articles/PMC16324/pdf/pq004285.pdf. 
16. Nelwan, Martin L. 2012. Higher Education with the Nelwan's Approach. Available at SSRN. http://ssrn.com/abstract=2133162. 